\title{
Family firms and leverage Empirical evidence from South East Asia
}

\author{
Hong Nhung Le ${ }^{1}$ \\ International University, Vietnam National University
}

\begin{abstract}
We investigate the impact of family ownership on leverage in South East Asia. East Asia provides ideal for studying the impact of family ownership status on leverage due to the predominant of family business form. We find that family firms use more debt than nonfamily firms. In addition, family firms with family CEOs are more aggressive in using debt than family firms with professional CEOs and non-family firms. Our results are robust to alternative estimation techniques and measurement of leverage. These findings contribute to understanding the financing behaviors among family-controlled firms in South East Asia.
\end{abstract}

Key word: Family firms, capital structure, South East Asia.

JEL classification: G30, G32.

1 School of Business, Quarter 6, Linh Trung Ward, Thu Duc District, HCMC, Vietnam. 


\section{INTRODUCTION}

A majority of firms around the world have the founder or the founder's family as large shareholders. Porta et al. (1999) find that founding families control over 53 percent of the largest publicly traded firms in 27 countries. Additionally, the prominent role of families in large firms is reported by Anderson and Reeb (2003a) and Villalonga and Amit (2006) for U.S.; Faccio and Lang (2002) for Europe; Claessens et al. (2000) and Carney and Child (2013) for East Asia. The prevalence of extensive family ownership and control is more pronounced outside the U.S., particularly in South East Asia where legal investor protection is weak (Porta et al., 1999).

The issue of extensive family ownership and control raises the primary conflicts of interests between family and minority shareholders, which are different from original conflicts in classical agency theory. On the one hand, the agency costs of family and minority shareholders in family firms are more severe than those in non-family firms (Demsetz and Lehn, 1985). On the other hand, agency costs of managerial and shareholders' interests are less severe with the presence of large family ownership (Jensen and Meckling, 1976). Founding families as large, undiversified blocking holders, are more risk averse (Anderson and Reeb, 2003b). These lead family firms to rely less on external debt financing or seek to risk reducing strategy through using less debt. However, controlling families may have incentives to systematically expropriate minority shareholder wealth (Demsetz and Lehn, 1985, Demsetz, 1983), leading to over-reliance on debt to enhance control power.

Empirical studies provide inconclusive results of the family influences on leverage. Mishra and McConaughy (1999) argue that leverage increases the cost of financial distress and the risk of losing control to creditors. Therefore, family firms among large public U.S. firms use less debt than non-family firms. Anderson and Reeb (2003b) find that family firms finance real investments not differently from non-family firms among U.S. largest public firms. Meanwhile, Ampenberger et al. (2013) find that family firms borrow less than non-family firms in Germany, a bank-based economy. 
In contrast, Driffield et al. (2007) and Singh (2016) find that family firms in East Asia borrow more than non-family firms. Driffield et al. (2007) argue that the separation of voting rights from cash flow rights give controlling shareholders incentives to extract scares resource of a firm for private benefits. Hence, family firms are motivated to maintain control power, leading founding families to be reluctant to issue stocks. Singh (2016) explains that the benefits of creditors' monitoring lead family firms in Indonesia to use more debt. Lo et al. (2016) and Brailsford et al. (2002) find a non-linear relationship between leverage and family ownership.

Using ultimate ownership data of 341 largest publicly traded firms in South East Asia countries including Indonesia, Malaysia, Philippines, Singapore, and Thailand, we find that founding family firms use more debt than non-family firms between 2004 and 2013. Our findings support the expropriation hypothesis that family firms over-rely on debt to enhance control power as debt is considered as an effective tool to raise capital without stock dilution (Demsetz, 1983, Demsetz and Lehn, 1985, Driffield et al., 2007). The results are robust to alternative family firm proxies and estimation methods. In addition, we consider active and passive family firms that have family members serving as firm's CEO and professional CEO from outside, respectively. The reason for this classification is that family control can be executed via ownership or power. An active family firm with family member serving as firm's CEO has both ownership and power. The presence of founding families in daily economic activities is more intensive.

The rest of the paper is structured as follows. Section 2 presents the literature review and proposed hypothesis. Section 3 presents data and methodology. Section 4 displays the results and discussion. Section 5 provides the conclusion.

\section{LITERATURE REVIEW AND HYPOTHESIS}

\section{Family firms and capital structure}

Empirical findings on the effect of family firms on leverage are rather inconclusive. Anderson and Reeb (2003b) find no difference in using debt financing between family firms versus non- 
family firms among S\&P 500 firms. Ampenberger et al. (2013) find a lower level of debt among family firms relative to non-family firms in Germany, a bank-based economy.

The findings of Ampenberger et al. (2013) is in line with Mishra and McConaughy (1999), who investigate the impact of family ownership on leverage among large U.S. firms. Their findings confirm that family firms are more risk adverse and concerned about their long-term survival. In contrast, Driffield et al. (2007) find that the debt level increases among family firms in four East Asian countries. In a study of family firms conducted in 38 countries, Ellul (2008) concludes that control power motivation influences family firms' capital structure more than risk reduction motivation.

According to classic agency theory, family-controlled firms should have less agency cost than non-family firms (Jensen and Meckling, 1976) as controlling families have great incentives to monitor managers of firms (Anderson and Reeb, 2003a). With CEO affiliated with controlling families in most family firms (Driffield et al., 2007), the conflicts of interests between managers and shareholders are naturally mitigated. However, family firms can create conflicts between family and minority shareholders because controlling families can exploit minority shareholders to achieve private benefits (Demsetz and Lehn, 1985). The possibility of expropriation is high in South East Asia where family firms often have a very large controlling shareholder with an edge of small shareholders (Claessens et al., 2000) and legal system of investor protection is weak (Porta et al., 1996).

As the large block, undiversified investors, founding families have greater risk aversion, leading risk-reducing motivation may influence family firm's financing decision. Thus, founding families have greater incentives to minimize the risk of firms (Anderson and Reeb, 2003b). Founding families may employ strategies to reduce risk such as using securities that have a low probability of default risk. Hence, they may prefer using equity to debt for raising capital. The agency cost of cash flows is not the main concern when family members usually serve as CEO/chairman (Daily and Dollinger, 1992). Hence, the benefit of debt as an effective tool to reduce agency cost of free cash flows (Jensen, 1986) is less important in family firms. 
is control motive.

A large body of literature reports the control motivation to expropriate minority shareholders in family firms (Demsetz, 1983, Demsetz and Lehn, 1985, Porta et al., 1999, Claessens et al., 2002, Villalonga and Amit, 2006, Shleifer and Vishny, 1986). The separation of control from cash flows rights in most family firms provides greater incentives and ability for controlling families to exploit minority shareholders. For example, controlling families may pursue socioemotional wealth for the family at the expense of the firm by using scarce resources of the firm (Block et al., 2013). Founding families who own a group of publicly traded and private firms may divert resources from public firms to benefit private firms, or family firms may invest less in R\&D (Chrisman and Patel, 2012, Block, 2012). When family shareholders have incentives to maintain control power in a firm, they are less willing to issue stock, as this will dilute their control power. Hence, they may prefer using debt instead of equity. We hypothesize that family firm use more debt than non-family firm.

\section{H: Family controlled firms use more debt than non-family firms}

\section{EMPIRICAL STRATEGY}

\subsection{Data}

We collect data from several sources. We obtain ownership data for publicly traded firms in four South East Asian countries (Indonesia, Malaysia, Philippines, Singapore, and Thailand) from the study of Carney and Child (2013). This data set is the most updated database of ownership in East Asia and identifies the ultimate controlling shareholders, ultimate cash flows (ownership) and voting (control) rights of firms in 2008. We exclude financial institutions (Anderson and Reeb, 2003b, Driffield et al., 2007, Ellul, 2008, Ampenberger et al., 2013). 
To control for the change in the type of ownership structure of firm during study period, we use database of Merger and Acquisition (M\&A) from Thompson Reuters during period of 2004 to 2013. We exclude firms which are target firms in such M\&A event took place during study period ${ }^{2}$.

Next, we extract firm financial data from Osiris and then match manually the ownership dataset with the firm financial data. After deleting firms with insufficient financial data, we end up with 2,373 firm-year observations.

Finally, we obtain macro factors including gross domestic product (GDP) growth rate, interest rate and inflation rate from the International Monetary Fund and legal origin, judicial enforcement, creditor, and anti-director indices from La Porta et al. (1997) and Djankov et al. (2007).

\subsection{Variables}

\section{Leverage}

We consider the long-term interest-bearing debt over the market value of a firm as a proxy for capital structure (De Jong et al., 2008, Titman and Wessels, 1988, Booth et al., 2001, Demirgüç-Kunt and Maksimovic, 1999). Long-term interest-bearing debt provides information on long-term capital raised by firms, which is consistent with the theoretical definition of capital structure as a mix of long-term debt and equity. Short-term debt often includes largely trade credit, which is influenced by completely different determinants (De Jong et al., 2008). Hence, leverage is measured by total debt ratio may lead to generate results, which are difficult to interpret. We use book value of debt due to difficulties in obtaining data to calculate the market value of debt. We use long-term debt over total assets as an alternative debt measurement for robustness checks.

Family firm

To distinguish between family and non-family firm, we follow the definition of a family firm in the study of Claessens et al. (2000) and Carney and Child (2013). They define it as a firm

\footnotetext{
${ }^{2}$ We do not include firms whose ownership structure change after M\&As due to huge time consuming on tracing ultimate ownership structure.
} 
a family. We use the threshold of 20 percent of voting rights follows the classification of Enriques and Volpin (2007). We design a dummy variable, Family_firm, equal to 1 if a firm is defined as a family firm, otherwise 0 .

In addition, we employ an alternative proxy for the family control. We use a dummy variable, Family_firm_CEO, equal to 1 if the firm has CEOs, Board Chairman, or Vice-Chairman affiliated with founding family, otherwise 0. Founding families can exercise the greatest influence on a firm by assigning one of family members in the position of CEO (Morck et al., 1988, Anderson and Reeb, 2003b, Driffield et al., 2007). We expect that the control entrenchment is greater among family firms with family CEOs relative to non-family firms or family firms with outside CEOs.

We also explore how the difference between control rights versus cash flow rights in family firms influences financing decisions. The incentives to expropriate wealth from minority shareholders are stronger when controlling families have influence exceeding their ownership rights (Faccio et al., 2001). The conflicts between family and non-family shareholders are more severe in East Asia firms when the wedge between cash flow and control rights is large (Faccio et al., 2001, Claessens et al., 2000). We compute the ratio of control over cash flow rights of a controlling family in a firm. This variable, Family_firm_control, measures the wedge between control and cash flow rights in a family firm. Family firms usually are characterized by personal contact (Voordeckers and Steijvers, 2006); therefore, the old family firm may have long-term bank relationship. This relationship may lead to well-established family firms borrowing easier realtive to non-family firms, or young family firms (Cucculelli et al., 2016, Ongena and Smith, 2001).

We investigate if the old and young family firms borrow differently or not by regressing the age of the family firm on the leverage.

Firm-specific factors 
opportunities are measured following previous empirical studies (Rajan and Zingales, 1995, De Jong et al., 2008, Booth et al., 2001). Size is the natural logarithm of total assets. Total fixed assets divided by total assets gives Tangibility. Profitability is measured by net income divided by total assets (ROA). Growth_opp is defined as market value divided by book value of the firm.

\section{Control variables}

We control for other factors which are expected to have an impact on firm leverage. First, we control for industry sector following previous studies (Titman and Wessels, 1988, Myers, 1984, Hall et al., 2000, Song and Philippatos, 2004). Next, we control for macroeconomic conditions such as real GDP growth rate (Huang and Ritter, 2009, De Jong et al., 2008, Booth et al., 2001), and interest rate (Huang and Ritter, 2009, Goldstein et al., 2001, El-Masry and Hyde, 2007). Leverage is cumulated from previous years (Frank and Goyal, 2009). Hence, to investigate the net impact of the firm-specific factor on the leverage, we include one year lagged leverage to control for cumulating of the leverage.

Furthermore, we control for some institutional environment factors including anti-director index, judicial index and creditor index following La Porta et al. (1997) who show that law and quality of enforcement are important determinants of firm's external financing.

To investigate the influence of family firm status on the determinants of leverage, we estimate the following specification:

$$
\text { lev }_{i t}=\alpha+\beta D_{\text {fam }_{i}}+\sum_{j=1}^{j} \gamma_{j} \text { Firm_factor }_{i t}+\sum_{k=1}^{k} \theta_{k} \text { Control }_{i t}+\varepsilon_{i t}
$$

\section{RESULTS AND DISCUSSION}

\subsection{Descriptive statistics}


Family firms use more debt than non-family firms except in 2010 (see figure 1).

We remark that family firms use more debt than non-family firms in Indonesia and Philippines (see table 2).

These countries have low quality of enforcement (low judicial index, less than 5 over 10) (see table 3). In contrast, family firms use less debt than non-family firms in Singapore and Malaysia, which have the high quality of enforcement (high judicial index, 9 over 10). There is no difference in using debt between family and non-family-firms.

Table 4 summarizes descriptive statistics of variables and $t$-test for difference in mean of four key firm-specific factors between family and non-family firms. Family firms use more debt than non-family firms. Family firms are smaller, less profitable and have the higher level of tangibility than non-family firms. There is no difference in growth opportunities between family and non-family firms.

\subsection{Results}

Table 5 provides our first results. Family firms use more debt than non-family firms in both leverage measurements (columns 1 and 5). The result is unchanged under alternative proxy for a family firm (columns 2 and 6). Debt is an effective tool to avoid ownership dilution; hence family firms may use debt to enhance control power (Demsetz and Lehn, 1985). The results show that in general, family firms are motivated by control power through using more debt than non-family firms. The incentives for wealth expropriation are stronger when the control rights exceed cash flow rights (Faccio et al., 2001, Claessens et al., 2002). Our results show that the

larger ratio of control over cash flow rights of the controlling family in the firm, the more debt family firm use (columns 3 and 7).

Similarly to study of Anderson and Reeb (2003b) and Driffield et al. (2007), we find that the age of the family firm has no impact on the leverage (columns 4 and 8).

\subsection{Robusness checks}


First, we check for outliers. Next, we run the regression with and without clustering at the firm level to control for heteroskedasticity and obtain similar results (columns 1 and 2). We rerun regression using panel correction standard error method (PCSE) following Beck (2008) and general least square (GLS). Again, we obtain similar results (columns 3 and 4).

\section{CONCLUSION}

We explore how family firm status affects the firm's financing decisions. We investigate 314 largest publicly traded firms in Southeast Asian countries including Indonesia, Malaysia, Philipines, Singapore, and Thailand. Our findings show that family firms borrow more than non-family firms during the period of 2004 to 2013. The results imply that the dilution entrenchment may lead family firms to rely more on debt as debt is an effective tool to raise capital without ownership dilution. Family firms are driven by control power motivation. We find a positive association between the level of debt family firms use and the ratio of control rights to cash flow rights. The larger ratio of control to cash flow rights, the more debt family firms borrow. The alternative leverage measurement and proxy for the family firm do not change our findings. 


\section{$2^{\text {nd }}$ International Conference on BUSINESS, MANAGEMENT \& ECONOMICS}

\section{REFERENCES}

Appendix: Variable definitions and Data Sources

\begin{tabular}{lll}
\hline Variable & Definition & Source \\
\hline Panel A: Leverage ratio measurement & \\
\hline Itd & $\begin{array}{l}\text { The ratio of long-term interest-bearing debt to market } \\
\text { value of the firm }\end{array}$ & $\begin{array}{l}\text { Authors' } \\
\text { calculation } \\
\text { based } \\
\text { Osiris }\end{array}$ \\
& & on \\
LTD & The ratio od long-term interest-bearing debt to total & As above \\
& assets
\end{tabular}

\section{Panel B: Family firm measurement}

Family_firm

A dummy variable equals 1 if the largest ultimate shareholder is family, otherwise 0

Family_firm_CEO

Family_control

\section{Panel C: Firm-level variables}

Family_firm_age

Fiscal year minus the year of establishment

A dummy variable equals 1 if a member of controlling family is also CEO, Chairman, or Vice-Chairman, otherwise 0

The ratio of control to cash flow rights in a family firm

As above
Authors'

calculation

based on

Carney and

Child (2013)

As above 


\section{$2^{\text {nd }}$ International Conference on BUSINESS, MANAGEMENT \& ECONOMICS}

Lagged_leverage Leverage ratio of the firm in previous year

\begin{tabular}{lll}
\hline Panel D: Country-level institutions & \\
\hline GDP_growth & Real GDP growth rate & $\begin{array}{l}\text { Authors' } \\
\text { calculations } \\
\text { based on IMF } \\
\text { source }\end{array}$ \\
Real_int & Real interest rate & $\begin{array}{l}\text { As above } \\
\text { Anti-index }\end{array}$ \\
Judicial & $\begin{array}{l}\text { Anti-director index measures the quality of investors' } \\
\text { right protection }\end{array}$ & $\begin{array}{l}\text { Porta et al. } \\
\text { Judicial index measures the quality of enforcement }\end{array}$ \\
\hline
\end{tabular}

Figure 1: Leverage over time

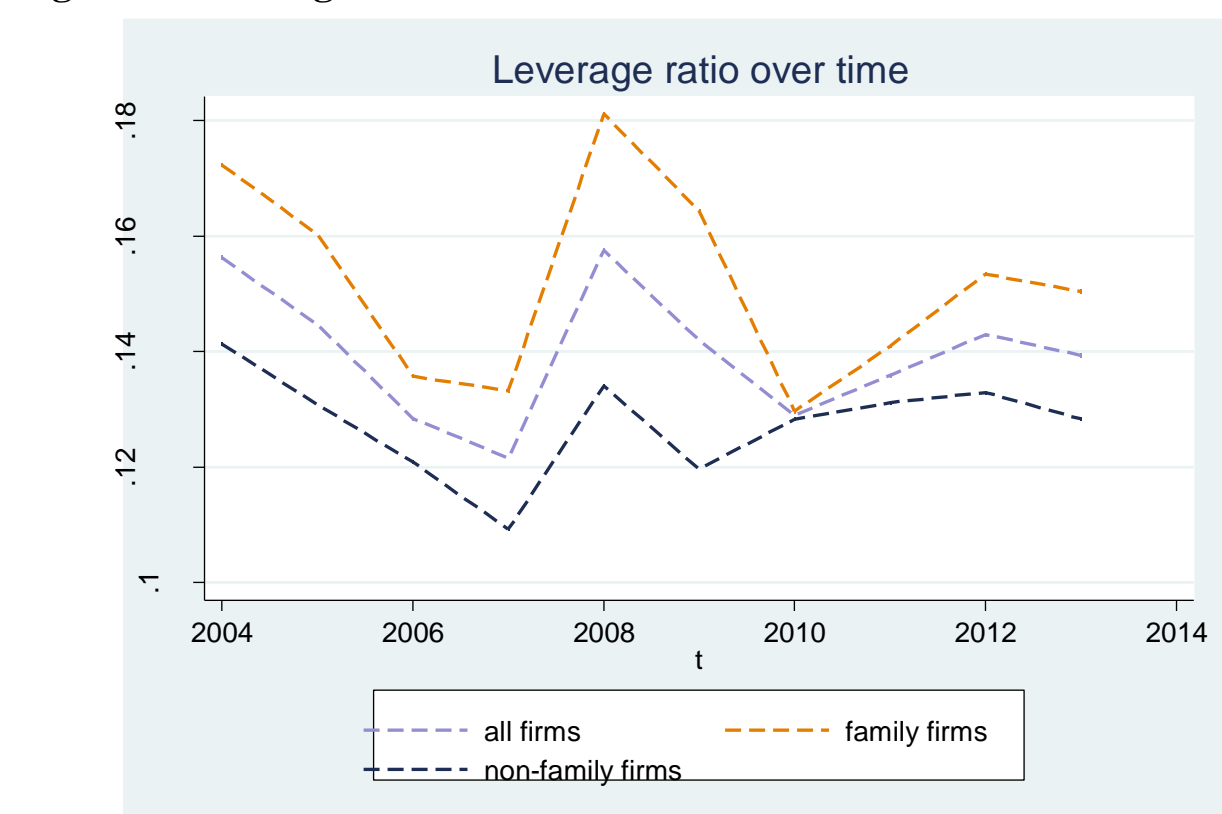

Authors'

calculations

based on IMF

Porta et al.

As above
$21-23$ JUNE 2019

VIENNA, AUSTRIA

As above 


\section{$2^{\text {nd }}$ International Conference on \\ BUSINESS, MANAGEMENT \& ECONOMICS}

21 - 23 JUNE 2019

VIENNA, AUSTRIA

Table 1: Family firms vs. non-family firms by industry

\begin{tabular}{|c|c|c|c|c|c|}
\hline \multirow{2}{*}{ Industry } & \multicolumn{2}{|l|}{ All firms } & \multicolumn{3}{|c|}{ All firms } \\
\hline & Number of firms & $\%$ & Family-firm & Non-family firm & Total \\
\hline \multirow{2}{*}{ Petroleum industry } & 14 & $4 \%$ & 1 & 13 & 14 \\
\hline & & & $7 \%$ & $93 \%$ & $100 \%$ \\
\hline \multirow{2}{*}{ Real estate industry } & 12 & $3 \%$ & 7 & 5 & 12 \\
\hline & & & $58 \%$ & $42 \%$ & $100 \%$ \\
\hline \multirow{2}{*}{ Consumer durables } & 62 & $16 \%$ & 33 & 29 & 62 \\
\hline & & & $53 \%$ & $47 \%$ & $100 \%$ \\
\hline \multirow{2}{*}{ Basic industry } & 53 & $14 \%$ & 30 & 23 & 53 \\
\hline & & & $57 \%$ & $43 \%$ & $100 \%$ \\
\hline \multirow{2}{*}{ Food/Tobacco industry } & 60 & $16 \%$ & 38 & 22 & 60 \\
\hline & & & $63 \%$ & $37 \%$ & $100 \%$ \\
\hline \multirow{2}{*}{ Construction industry } & 26 & $7 \%$ & 11 & 15 & 26 \\
\hline & & & $42 \%$ & $58 \%$ & $100 \%$ \\
\hline \multirow{2}{*}{ Capital goods industry } & 15 & $4 \%$ & 9 & 6 & 15 \\
\hline & & & $60 \%$ & $40 \%$ & $100 \%$ \\
\hline \multirow{2}{*}{ Transportation industry } & 27 & $7 \%$ & 10 & 17 & 27 \\
\hline & & & $37 \%$ & $63 \%$ & $100 \%$ \\
\hline \multirow{2}{*}{ Utilities industry } & 43 & $11 \%$ & 15 & 28 & 43 \\
\hline & & & $35 \%$ & $65 \%$ & $100 \%$ \\
\hline \multirow{2}{*}{ Textile/Trade industry } & 26 & $7 \%$ & 14 & 12 & 26 \\
\hline & & & $54 \%$ & $46 \%$ & $100 \%$ \\
\hline \multirow{2}{*}{ Services industry } & 17 & $4 \%$ & 7 & 10 & 17 \\
\hline & & & $41 \%$ & $59 \%$ & $100 \%$ \\
\hline \multirow{2}{*}{ Leisure industry } & 23 & $6 \%$ & 14 & 9 & 23 \\
\hline & & & $61 \%$ & $39 \%$ & $100 \%$ \\
\hline \multirow{2}{*}{ Total } & 378 & $100 \%$ & 189 & 189 & 378 \\
\hline & & & $50 \%$ & $50 \%$ & $100 \%$ \\
\hline
\end{tabular}




\section{$2^{\text {nd }}$ International Conference on BUSINESS, MANAGEMENT \& ECONOMICS}

\section{Table 2: Long-term debt ratios by country}

This table reports the results of univariate tests for difference in leverage between family firms and non-family firms. The sample is composed of 2,373 firm-year observations representing 341 unique firms over the period 2004-2013. Definitions and data sources for the variables are provided in the Appendix. ***,**,* denote statistical significance at the $1 \%, 5 \%$, and $10 \%$ levels, respectively.

\begin{tabular}{lcccccc}
\hline & $\begin{array}{c}\text { Full } \\
\text { sample }\end{array}$ & Indonesia & Malaysia & Philippines & Singapore & Thailand \\
\hline Non-family firms & .1267 & .1609 & .1535 & .1337 & .1321 & .1728 \\
Family firms & .1489 & .2294 & .1307 & .1697 & .1118 & .1831 \\
All firms & .1328 & .2021 & .1432 & .1633 & .1219 & .1758 \\
\hline $\begin{array}{l}\text { Diff. family vs non-family } \\
\text { firms }\end{array}$ & $-.0161^{\star *}$ & $-.0685^{\star * *}$ & $.0228^{* * *}$ & $-.0361^{\star *}$ & $.0203^{* *}$ & -.0103 \\
& $(-4.3208)$ & $(-4.3915)$ & $(2.3472)$ & $(-1.8000)$ & $(1.9353)$ & $(-0.7855)$ \\
\hline
\end{tabular}

Table 3: Institutional environment index by country

Source: country origin and an average of creditor right indicator come from Djankov, S., McLiesh, C., Shleifer, A., 2007. Private Credit in 129 Countries. Journal of Financial Economics 84, 299-329. Anti-director index and judicial come from Porta, Rafael La, Lopez-de-Silane, Florencio Shleifer, Andrei Vishny, Robert W., 1996. Law and Finance. National Bureau of Economic Research.

\begin{tabular}{lccccc}
\hline & Indonesia & Malaysia & Philippines & Singapore & Thailand \\
\hline Country origin & Civil & Common & Civil & Common & Civil \\
Anti-director index & 2 & 3 & 4 & 3 & 3 \\
Creditor right & 2 & 3 & 1 & 3 & 2 \\
Judicial & 2.5 & 9 & 4.75 & 10 & 3.25 \\
\hline
\end{tabular}




\section{$2^{\text {nd }}$ International Conference on BUSINESS, MANAGEMENT \& ECONOMICS}

\section{Table 4: Descriptive statistics and univariate tests}

This table reports the results of univariate tests for differences between family firms and non-family firms. The sample is composed of 2,373 firm-year observations representing 341 unique firms over the period 2004-2013. Definitions and data sources for the variables are provided in the Appendix. ***,**, denote statistical significance at the $1 \%, 5 \%$, and $10 \%$ levels, respectively.

\begin{tabular}{|c|c|c|c|c|c|c|}
\hline \multicolumn{7}{|c|}{ Panel A: Summary statistic } \\
\hline Variable & $\mathbf{N}$ & Mean & SD & Median & Min & Max \\
\hline Long-term leverage & 2643 & 0.14 & 0.14 & 0.10 & 0.00 & 0.81 \\
\hline Size & 3769 & 12.85 & 1.69 & 12.85 & 3.83 & 17.82 \\
\hline Tangibility & 3769 & 0.56 & 0.22 & 0.57 & 0.00 & 1.00 \\
\hline Profitability & 3758 & 0.09 & 0.12 & 0.08 & -0.97 & 0.88 \\
\hline Growth_opp & 3270 & 2.35 & 21.79 & 1.19 & 0.16 & 976.57 \\
\hline Real_int & 3860 & 0.04 & 0.02 & 0.04 & -0.01 & 0.10 \\
\hline Anti-index & 3860 & 2.92 & 0.59 & 3.00 & 2.00 & 4.00 \\
\hline Creditor_Right & 3860 & 2.26 & 0.69 & 2.00 & 1.00 & 3.00 \\
\hline Judicial & 3860 & 5.77 & 3.08 & 4.75 & 2.50 & 10.00 \\
\hline GDPgrowth & 3860 & 0.05 & 0.04 & 0.04 & -0.06 & 0.18 \\
\hline \multicolumn{7}{|c|}{ Panel B: Univariate Tests: Family Firms versus Non-family Firms } \\
\hline & Non-family firm & Family firm & T-test & & & \\
\hline Long-term leverage & 0.13 & 0.15 & $(-4.32)^{* * *}$ & & & \\
\hline Size & 13.07 & 12.61 & $(8.41)^{\star * *}$ & & & \\
\hline Tangibility & 0.55 & 0.58 & $(-4.45)^{\star \star \star}$ & & & \\
\hline Profitability & 0.09 & 0.08 & $(3.01)^{* *}$ & & & \\
\hline Growth opp. & 1.69 & 3.03 & $(-1.76)$ & & & \\
\hline Observations & 1914 & 1914 & 3769 & & & \\
\hline
\end{tabular}




\section{Table 5: Family firms and leverage}

This table reports the OLS regressions of family firms on leverage. The sample is composed of 2,373 firm-year observations representing 341 unique firms over the period 2004-2013. The dependent variable is long-term leverage. Definition of variables appears in Appendix. A dummy variable for industry sector are included in the regressions but are not reported. Robust standard error adjusted for clustering by the firm are reported in parentheses. ***,**,* denote statistical significance at the $1 \%, 5 \%$, and $10 \%$ levels, respectively.

\begin{tabular}{|c|c|c|c|c|c|c|c|c|}
\hline & \multicolumn{4}{|c|}{ Long-term debt/Market value of firm } & \multicolumn{4}{|c|}{ Long-term debt/Total assets } \\
\hline & 1 & 2 & 3 & 4 & 5 & 6 & 7 & 8 \\
\hline \multirow[t]{2}{*}{ Family_firm } & $0.0131^{* * *}$ & & & & $0.0116^{\star * *}$ & & & \\
\hline & $(0.0043)$ & & & & $(0.0040)$ & & & \\
\hline \multirow[t]{2}{*}{ Family_firm_CEO } & & $0.0118^{* *}$ & & & & $0.0148^{* * *}$ & & \\
\hline & & $(0.0045)$ & & & & $(0.0046)$ & & \\
\hline \multirow[t]{2}{*}{ Family_control } & & & $0.0035^{\star \star *}$ & & & & $0.0029^{* *}$ & \\
\hline & & & $(0.0013)$ & & & & $(0.0012)$ & \\
\hline \multirow[t]{2}{*}{ Family_firm_age } & & & & 0.0000 & & & & 0.0000 \\
\hline & & & & 0.0000 & & & & 0.0000 \\
\hline \multirow[t]{2}{*}{ Size } & $0.0086^{\star * \star}$ & $0.0083^{* * *}$ & $0.0088^{* * *}$ & $0.0119^{* * *}$ & $0.0076^{* * *}$ & $0.0075^{\star * *}$ & $0.0078^{* * *}$ & $0.0101^{\star * *}$ \\
\hline & $(0.0020)$ & $(0.0020)$ & $(0.0020)$ & $(0.0030)$ & $(0.0018)$ & $(0.0018)$ & $(0.0019)$ & $(0.0025)$ \\
\hline Tangibility & $0.0636^{\star \star *}$ & $0.0656^{\star \star *}$ & $0.0641^{\star * *}$ & $0.0849^{\star * *}$ & $0.0678^{\star \star *}$ & $0.0700^{\star * *}$ & $0.0684^{* * *}$ & $0.0711^{* * *}$ \\
\hline
\end{tabular}




\section{ICBMECONF}

\section{$2^{\text {nd }}$ International Conference on}

\section{BUSINESS, MANAGEMENT \& ECONOMICS}

\begin{tabular}{|c|c|c|c|c|c|c|c|c|}
\hline & $(0.0122)$ & $(0.0123)$ & $(0.0121)$ & $(0.0208)$ & $(0.0127)$ & $(0.0126)$ & $(0.0125)$ & $(0.0196)$ \\
\hline \multirow[t]{2}{*}{ Profitability } & $-0.1168^{\star \star *}$ & $-0.1138^{\star \star \star}$ & $-0.1177^{\star \star \star *}$ & $-0.0972^{\star \star \star}$ & $-0.1999^{\star * *}$ & $-0.1975^{\star \star *}$ & $-0.2011^{* * *}$ & $-0.2049^{* * *}$ \\
\hline & $(0.0298)$ & $(0.0296)$ & $(0.0300)$ & $(0.0312)$ & $(0.0487)$ & $(0.0478)$ & $(0.0490)$ & $(0.0645)$ \\
\hline \multirow[t]{2}{*}{ Growth_opp } & $-0.0079^{* *}$ & $-0.0077^{\star \star}$ & $-0.0080^{* *}$ & $(0.0078)$ & $0.0096^{\star * *}$ & $0.0099^{* * *}$ & $0.0094^{\star * *}$ & $0.0127^{\star *}$ \\
\hline & $(0.0038)$ & $(0.0039)$ & $(0.0038)$ & $(0.0063)$ & $(0.0035)$ & $(0.0036)$ & $(0.0035)$ & $(0.0050)$ \\
\hline \multirow[t]{2}{*}{ Lagged_leverage } & $0.6935^{\star * *}$ & $0.6960^{\star * *}$ & $0.6954^{* * *}$ & $0.6977^{\star \star \star}$ & $0.7504^{\star \star \star}$ & $0.7501^{* \star *}$ & $0.7518^{\star \star \star}$ & $0.7693^{\star * \star}$ \\
\hline & $(0.0321)$ & $(0.0323)$ & $(0.0323)$ & $(0.0297)$ & $(0.0437)$ & $(0.0432)$ & $(0.0445)$ & $(0.0442)$ \\
\hline \multirow[t]{2}{*}{ GDP_growth } & $(0.0178)$ & $(0.0147)$ & $(0.0045)$ & 0.0414 & $(0.0470)$ & $(0.0467)$ & $(0.0341)$ & $(0.0847)$ \\
\hline & $(0.0443)$ & $(0.0443)$ & $(0.0448)$ & $(0.0635)$ & $(0.0500)$ & $(0.0505)$ & $(0.0495)$ & $(0.0831)$ \\
\hline \multirow[t]{2}{*}{ Real_int } & $-0.5699^{* * *}$ & $-0.5617^{* * *}$ & $-0.5426^{* * *}$ & $-0.5708^{* * *}$ & 0.0222 & 0.0207 & 0.0487 & 0.0374 \\
\hline & $(0.1068)$ & $(0.1057)$ & $(0.1063)$ & $(0.1484)$ & $(0.0921)$ & $(0.0922)$ & $(0.0918)$ & $(0.1373)$ \\
\hline \multirow[t]{2}{*}{ anti-index } & $-0.0149^{\star \star *}$ & $-0.0145^{\star * *}$ & $-0.0137^{\star \star *}$ & $-0.0127^{\star *}$ & $-0.0081^{*}$ & $-0.0083^{* *}$ & $-0.0069^{*}$ & $(0.0072)$ \\
\hline & $(0.0045)$ & $(0.0044)$ & $(0.0045)$ & $(0.0056)$ & $(0.0041)$ & $(0.0041)$ & $(0.0040)$ & $(0.0049)$ \\
\hline \multirow[t]{2}{*}{ Judicial } & $-0.0035^{\star \star *}$ & $-0.0035^{\star * *}$ & $-0.0034^{\star \star *}$ & $-0.0032^{\star \star}$ & $-0.0016^{\star \star}$ & $-0.0016^{\star \star}$ & $-0.0015^{\star \star}$ & $-0.0022^{*}$ \\
\hline & $(0.0008)$ & $(0.0008)$ & $(0.0008)$ & $(0.0014)$ & $(0.0007)$ & $(0.0007)$ & $(0.0007)$ & $(0.0012)$ \\
\hline \multirow[t]{2}{*}{ Intercept } & $(0.0285)$ & $(0.0281)$ & $(0.0320)$ & $-0.0940^{\star *}$ & $-0.0932^{\star * *}$ & $-0.0946^{\star * *}$ & $-0.0962^{* * *}$ & $-0.1256^{\star * *}$ \\
\hline & $(0.0313)$ & $(0.0315)$ & $(0.0314)$ & $(0.0469)$ & $(0.0302)$ & $(0.0300)$ & $(0.0307)$ & $(0.0434)$ \\
\hline Obs. & 2373 & 2373 & 2373 & 1199 & 2480 & 2480 & 2480 & 1252 \\
\hline Adj.R2 & 0.6962 & 0.6957 & 0.6954 & 0.7301 & 0.7201 & 0.7206 & 0.7195 & 0.7489 \\
\hline
\end{tabular}

\section{1 - 23 JUNE 2019}

VIENNA, AUSTRIA 


\section{Table 6: Robustness tests}

This table reports regressions of family firm status on leverage and the moderating effect of family firm status on the relationship between the firm-specific factor and the leverage. The sample is composed of 2,373 firmyear observations representing 341 unique firms over the period 2004-2013. The dependent variable is long-term leverage. Definition of variables appears in Appendix. Size, Tangibility, Profitability, real GDP growth rate, real interest rate, anti-director index, Judicial, dummy variable for industry sector are included in the regressions but are not reported. Robust standard error adjusted for clustering by a firm are reported in parentheses. ***, **, * denote statistical significance at the $1 \%, 5 \%$, and $10 \%$ levels, respectively.

\begin{tabular}{lcccc}
\hline & $\begin{array}{c}\text { Model 1 } \\
\text { (OLS) }\end{array}$ & $\begin{array}{c}\text { Model 2 } \\
\text { (Cluster by } \\
\text { Firms) }\end{array}$ & $\begin{array}{c}\text { Model 3 } \\
\text { (GLS) }\end{array}$ & $\begin{array}{c}\text { Model 4 } \\
\text { (PCSE) }\end{array}$ \\
\hline $\begin{array}{l}\text { Panel A: The largest ultimate shareholder } \\
\text { family }\end{array}$ & & & & \\
\hline Family_firm & $0.0131^{* * *}$ & $0.0131^{* * *}$ & $0.0060^{* * *}$ & $0.0131^{* * *}$ \\
& $(0.0035)$ & $(0.0043)$ & $(0.0018)$ & $(0.0035)$ \\
\hline
\end{tabular}

Panel B: A member of controlling family is also CEO, Chairman, or Vice-Chairman

\begin{tabular}{lcccc}
\hline Family_firm_CEO & $\begin{array}{c}0.0118^{* * *} \\
(0.0037)\end{array}$ & $0.0118^{* *}$ & $0.0069^{* * *}$ & $0.0118^{* * *}$ \\
& & $(0.0045)$ & $(0.0018)$ & $(0.0037)$
\end{tabular}

